\title{
The Impacts of the Shrinkage in Goods Exports on Chinese Economy: A CGE Model-Based Scenario Analysis
}

\author{
Lin $\operatorname{Sun}^{1}$ \\ ${ }^{1}$ Shanghai Academy of Social Sciences, Shanghai, China \\ Correspondence: Lin Sun, Shanghai Academy of Social Sciences, Shanghai, 200020, China. Tel: \\ 86-135-0163-0511. E-mail: sunlin@sass.org.cn
}

Received: August 22, 2019

doi:10.5539/ass.v15n10p130
Accepted: September 5, $2019 \quad$ Online Published: September 29, 2019

URL: https://doi.org/10.5539/ass.v15n10p130

\begin{abstract}
Focusing on the shrinkage in goods exports, this paper quantitatively analyzes the impacts of Sino-US trade war on growth, trade, industrial production of China. The method used here is a dynamic simulation for the period from 2019 to 2030 based on a recursively dynamic CGE model of 18 industries. The impacts are analyzed and assessed by providing 5 alternative scenarios and by comparing their deviations from the baseline scenario. Three alternative scenarios are diffident forms of reduction in goods exports, and two alternative scenarios are diffident hedging measures to the impacts. A comparison of alternative scenarios reveals that the reduction in goods exports will significantly affect the nominal GDP but cause trouble for the real GDP of China. As the hedging measure, the currency depreciation ultimately only affects the price, and the effect on the real GDP is very limited. To increase the domestic real investment will result in the increase in imports and significantly hedge the loss of nominal GDP and cause a larger-scale trade deficit, and therefore need to be used with caution.
\end{abstract}

Keywords: Sino-US Trade War, Shrinkage in Goods Exports, Chinese Economy, CGE Model

\section{Introduction}

Since March 2018, China and the United States have been engaged in a trade war as each country continues to dispute tariffs placed on goods traded between them. July 15, 2018, Trump administration set $25 \%$ tariffs on $\$ 34$ billions of Chinese imports. China responded in kind with tariffs on $\$ 34$ billion of the United States. August 7 , 2018 , the United States released the list of $\$ 16$ billions of Chinese goods to be subject to $25 \%$ tariffs. China retaliated with $25 \%$ duties on $\$ 16$ billion of the United States goods. September 24, 2018, Trump administration implemented $10 \%$ tariffs on $\$ 200$ billions of Chinese imports and planned to increase the rate to $25 \%$ on January 1, 2019. China answered with duties of its own on $\$ 60$ billion of the United States goods. December 1, 2018, the United States and China agreed on a 90-day halt to new tariffs. Trump administration agreed to put off January 1, 2019, scheduled increase on tariffs on $\$ 200$ billions of Chinese goods until early March while talks between the two countries take place. China agreed to buy more products from the United States. But after more than a year of friction and ten rounds of negotiations, China and the United States ultimately did not reach an agreement. As a result, the two countries entered the second round of retaliatory mutual tariffs. May 10, 2019, Trump administration raised tariffs on $\$ 200$ billions of Chinese imports to $25 \%$ from $10 \%$. Negotiations are deadlocked until G20 Summit in Japan.

China has been strengthening its linkage with the world economy and the United States steadily after became the membership of WTO from 2001. As shown in Table 1, for the period 2001-2018, real GDP of China increased by 10.2 times, total trade to the world increased by 9.1 times, exports to the world by 9.3 times, and imports to the world by 8.8 times (in nominal US dollars), total trade to the United States increased by 7.9 times, exports to the United States by 8.8 times, and imports to the United States by 5.9 times (in nominal US dollars). The trade surplus of China increased 15.6 times to the world and 11.5 times to the United States. During the period 2001-2018, the trade surplus to the United States accounted for which to the world, the highest more than $250 \%$ and the lowest also more than $40 \%$, and more than $73.5 \%$ of the trade surplus of this period was from the United States. 2005-2007, the total trade of China accounted for more than $60 \%$ of GDP and still exceeded $30 \%$. In other words, China has become the big player in the world economy, and for the Chinese economy, the trade with the world, especially the exports to the United States is very important.

The economic environment surrounding China is being gradually changed because of the Sino-US trade war. 
Trade wars have a major impact on the Chinese Economy, there has been some research studying related issues. Li et al. (2018) use a multi-country global general equilibrium (GE) model to numerically simulate the effects of possible Sino-US trade wars. Their simulation results show that China will be significantly hurt by the Sino-US trade war, but negative impacts are affordable. Shagdar \& Nakajima (2018) analyzed the economic effects of the ongoing Sino-US trade war by using a CGE Model and GTAP Data Base 9.0a, the results show that both parties will be worse-off from this trade friction, having welfare losses and real GDP contractions, and the negative economic and trade impacts on China would be larger compared to those of the USA. Tsutsumi (2018) analyzed the potential impact of the proposed tariff increases by a global CGE model. The results show that the additionally imposed tariffs on goods alone decline the GDP in the US and China by $0.1 \%$ and $0.2 \%$, respectively. Considering the effect of capital deepening and technological spillover induced by trade, the GDP in the US and China declines by $1.6 \%$ and $2.5 \%$ respectively.

The above researches are based on the multi-national model and mainly study the impact of the Sino-US trade war on China and the United States and other countries, and lack the internal view of the Chinese economy. Focusing on easy quantifiable changes such as the shrinkage in goods exports of China, this paper quantitatively analyzes impacts of the trade war on GDP growth, industrial structure, and the balance of payments. The method used here is a dynamic simulation for the period from 2015 (benchmark) to 2030 based on a recursively dynamic CGE (Computable General Equilibrium) model of 18 industries. Section 2 presents the CGE model of the Chinese economy. Section 3 provides simulation analyses on the impacts of the shrinkage in goods exports of China. Section 4 is the summary and conclusion.

Table 1. China's GDP and Trade with the World and U.S. (2001-2018, billion US\$)

\begin{tabular}{|c|c|c|c|c|c|c|c|c|c|c|c|c|c|c|}
\hline Year & $\begin{array}{c}(\mathrm{A}+\mathrm{B}) \\
/ \mathrm{RGDP} \\
(\%)\end{array}$ & $\begin{array}{c}(\mathrm{C}+\mathrm{D}) \\
/ \mathrm{A} \\
(\%)\end{array}$ & $\begin{array}{l}\mathrm{C} / \mathrm{A} \\
(\%)\end{array}$ & $\begin{array}{l}\mathrm{D} / \mathrm{B} \\
(\%)\end{array}$ & $\begin{array}{c}(\mathrm{C}-\mathrm{D}) \\
/(\mathrm{A}-\mathrm{B}) \\
(\%)\end{array}$ & $\begin{array}{l}\text { Real } \\
\text { GDP }\end{array}$ & $\begin{array}{l}\text { Total } \\
\text { Export } \\
\text { (A) }\end{array}$ & $\begin{array}{l}\text { Total } \\
\text { Import } \\
\text { (B) }\end{array}$ & $\begin{array}{l}\text { Total } \\
\text { Trade } \\
(\mathrm{A}+\mathrm{B})\end{array}$ & $\begin{array}{c}\text { Total } \\
\text { Net } \\
\text { Export } \\
\text { (A-B) }\end{array}$ & $\begin{array}{c}\text { Export } \\
\text { to US } \\
\text { (C) }\end{array}$ & $\begin{array}{l}\text { Import } \\
\text { from } \\
\text { US } \\
\text { (D) }\end{array}$ & $\begin{array}{c}\text { Trade } \\
\text { with } \\
\text { US } \\
(\mathrm{C}+\mathrm{D})\end{array}$ & $\begin{array}{l}\text { Net } \\
\text { Export } \\
\text { to US } \\
\text { (C-D) }\end{array}$ \\
\hline 2001 & 38.1 & 15.8 & 20.4 & 10.8 & 124.6 & 1339 & 266 & 244 & 510 & 23 & 54 & 26 & 80 & 28 \\
\hline 2002 & 42.2 & 15.7 & 21.5 & 9.2 & 140.4 & 1471 & 326 & 295 & 621 & 30 & 70 & 27 & 97 & 43 \\
\hline 2003 & 51.3 & 14.8 & 21.1 & 8.2 & 230.1 & 1660 & 438 & 413 & 851 & 25 & 92 & 34 & 126 & 59 \\
\hline 2004 & 59.0 & 14.7 & 21.1 & 8.0 & 250.1 & 1955 & 593 & 561 & 1155 & 32 & 125 & 45 & 170 & 80 \\
\hline 2005 & 62.2 & 14.9 & 21.4 & 7.4 & 112.0 & 2287 & 762 & 660 & 1422 & 102 & 163 & 49 & 212 & 114 \\
\hline 2006 & 64.0 & 14.9 & 21.0 & 7.5 & 81.3 & 2753 & 969 & 791 & 1760 & 178 & 203 & 59 & 263 & 144 \\
\hline 2007 & 61.3 & 13.9 & 19.1 & 7.3 & 61.9 & 3552 & 1220 & 956 & 2176 & 264 & 233 & 69 & 302 & 163 \\
\hline 2008 & 55.8 & 13.0 & 17.6 & 7.2 & 57.4 & 4597 & 1431 & 1133 & 2563 & 298 & 252 & 81 & 334 & 171 \\
\hline 2009 & 43.3 & 13.5 & 18.4 & 7.7 & 73.2 & 5102 & 1202 & 1006 & 2208 & 196 & 221 & 77 & 298 & 143 \\
\hline 2010 & 48.9 & 13.0 & 18.0 & 7.3 & 99.8 & 6088 & 1578 & 1396 & 2974 & 182 & 283 & 102 & 385 & 181 \\
\hline 2011 & 48.2 & 12.3 & 17.1 & 7.0 & 130.6 & 7555 & 1898 & 1743 & 3642 & 155 & 324 & 122 & 447 & 202 \\
\hline 2012 & 45.3 & 12.5 & 17.2 & 7.3 & 95.0 & 8532 & 2049 & 1818 & 3867 & 230 & 352 & 133 & 485 & 219 \\
\hline 2013 & 43.4 & 12.5 & 16.7 & 7.8 & 83.4 & 9574 & 2209 & 1950 & 4159 & 259 & 368 & 152 & 521 & 216 \\
\hline 2014 & 41.2 & 12.9 & 16.9 & 8.1 & 61.9 & 10440 & 2342 & 1959 & 4302 & 383 & 396 & 159 & 555 & 237 \\
\hline 2015 & 35.9 & 14.1 & 18.0 & 8.8 & 44.0 & 11014 & 2273 & 1680 & 3953 & 594 & 409 & 148 & 557 & 261 \\
\hline 2016 & 33.1 & 14.1 & 18.4 & 8.5 & 49.2 & 11142 & 2098 & 1588 & 3686 & 510 & 385 & 134 & 520 & 251 \\
\hline 2017 & 33.8 & 14.2 & 19.0 & 8.3 & 65.7 & 12156 & 2263 & 1844 & 4107 & 420 & 430 & 154 & 584 & 276 \\
\hline 2018 & 34.0 & 13.7 & 19.2 & 7.3 & 91.9 & 13605 & 2487 & 2136 & 4623 & 352 & 478 & 155 & 634 & 323 \\
\hline Avg. & 46.7 & 13.9 & 19.0 & 8.0 & 102.9 & 10.2 & 9.3 & 8.8 & 9.1 & 15.6 & 8.8 & 5.9 & 7.9 & 11.5 \\
\hline
\end{tabular}

Note. The last row, column 2-6 is arithmetic average of 2001-2018; column 7 to 15 is times of 2018/2001. Source: China Statistical Yearbook 2018 (Data for 2018 from online).

\section{CGE Model of the Chinese Economy}

\subsection{Characteristics of the Model}

The CGE model of China in this paper uses the latest input-output table of 2015 for the Chinese economy. The model consists of 18 industries (agriculture, 3 energy industries, 8 manufacturing industries including construction, and 6 service industries), 1 private consuming sector, and 1 kind of labor. The model is a simple version of the automobile-related Hybrid CGE model of China (Sun, 2012), and the basic structure based on the model used to study the policies of Chinese trade liberalization (Ezaki \& Sun, 2000). It originates basically from 
the CGE model of an open economy in Dervis, De Melo, and Robinson (1982). The model here is a dynamic recursive model, is solved year by year dynamically by using extrapolated values on such exogenous variables and parameters. The detailed structure of the model can be found in Ezaki \& Sun (2000) and Sun (2012).

\subsection{The Dataset and Baseline of Model for the Chinese Economy}

Table 2 is a minimal version of the benchmark information of 2015 Social Accounting Matrix (SAM). The parameters of the model are calibrated on the basis of the information contained in the full SAM. The SAM shows the balance between demand and supply in the output market, the balance between aggregate savings and investment, the budgetary balance of various actors, and the balance in the transactions with the world market. The SAM is based on China input-output table of 2015 and other macroeconomic and sectoral information pertaining to that year obtained from China Statistical Yearbook 2016. The model uses three kinds of elasticity pertaining to CES and CET functions. GTAP data is used to obtain the elasticity of substitution between labor and capital and between imports and domestic goods. The evidence available in other studies is used to obtain the elasticity of transformation between domestically output and export.

Baseline scenario (S0) is the standard simulation result for 2015-2030 to be used as the base in comparison. The baseline needs to be reasonable, reflecting what would have happened if the recent trends by and large continued, and parameter values did not change too much. In order to get the baseline scenario, we must assign proper values to exogenous variables and parameters, including elasticity of substitution and transformation of various CES functions. For major exogenous variables, we assume the growth rate of labor supply, real investment, and TFP of each industry, respectively during 2015-2030. These values accord well with the recent experience. Scale parameter of exports and imports in each industry is extrapolated based on the growth performance of exports and imports in the past. The exchange rate is fixed at the 2015 level (zero growth), and the coefficients of intermediate inputs are assumed to remain the same as in the 2015 input-output table.

Table 2. Social Accounting Matrix (SAM) of China, 2015 in 100 Million Yuan



\begin{tabular}{|c|c|c|c|c|c|c|c|c|c|c|}
\hline Activities & & 1932998 & & & & & & & 148448 & 2081447 \\
\hline Commodities & 1401192 & & & & & 265980 & 97053 & 293925 & & 2058151 \\
\hline Capital & 243869 & & & & & & & & & 243869 \\
\hline Labor & 354110 & & & & & & & & & 354110 \\
\hline Enterprises & & & 243869 & & & & & & & 243869 \\
\hline Households & & & & 345493 & 216736 & & & & & 562229 \\
\hline Government & 82275 & & & 8617 & 27133 & & & & & 118025 \\
\hline Savings & & & & & & 296249 & 20971 & & -23295 & 293925 \\
\hline Import from World & & 125153 & & & & & & & & 125153 \\
\hline Total & 2081447 & 2058151 & 243869 & 354110 & 243869 & 562229 & 118025 & 293925 & 125153 & \\
\hline
\end{tabular}

Table 3 presents the baseline scenario in terms of average growth rates of key macroeconomic variables and gross value added by industry during 2019-2030. As we can see, under the baseline scenario, the real GDP of China is to grow at an annual average rate of 6.37 percent, nominal GDP is $8.74 \%$ and the GDP deflator is $2.2 \%$. Real import from the world market is to grow at a rate of $4.37 \%$. On the other hand, export to the world market is to grow at an annual average rate of $4.97 \%$. The baseline scenario, therefore, reflects the current trend of the increasing dependence of China on the world market as a source of consumption.

Table 3. The Baseline of Chinese Economy, 2019-2020 (100 Million Yuan)

\begin{tabular}{|c|c|c|c|c|c|c|c|c|c|c|c|c|c|}
\hline & $\%$ & 2019 & 2020 & 2021 & 2022 & 2023 & 2024 & 2025 & 2026 & 2027 & 2028 & 2029 & 2030 \\
\hline Nominal GDP & 8.74 & 915223 & 990065 & 107198 & 116157 & 126000 & 136830 & 148756 & 161907 & 176429 & 192487 & 2102646 & 229980 \\
\hline Real GDP & 6.37 & 872961 & 928678 & 987903 & 105091 & 111789 & 118909 & 126481 & 134534 & 143103 & 152220 & 1619244 & 172254 \\
\hline GDP Deflator & 2.22 & 1.05 & 1.07 & 1.09 & 1.11 & 1.13 & 1.15 & 1.18 & 1.20 & 1.23 & 1.26 & 1.30 & 1.34 \\
\hline Real Consumption & 6.22 & 324137 & 343678 & 364505 & 386726 & 410438 & 435756 & 462808 & 491734 & 522682 & 555816 & 591313 & 629365 \\
\hline
\end{tabular}




\begin{tabular}{|c|c|c|c|c|c|c|c|c|c|c|c|c|c|}
\hline Real Gov Consumption & 5.26 & 117490 & 123750 & 130327 & 137238 & 144498 & 152124 & 160132 & 168541 & 177370 & 186637 & 196363 & 206566 \\
\hline Real Exports & 4.94 & 182046 & 191216 & 200811 & 210867 & 221377 & 232356 & 243830 & 255818 & 268339 & 281417 & 295073 & 309325 \\
\hline Real Imports & 4.37 & 146319 & 152275 & 158555 & 165160 & 172149 & 179548 & 187384 & 195685 & 204486 & 213823 & 223731 & 234258 \\
\hline Real Trade Surplus & 6.98 & 35727 & 38940 & 42255 & 45707 & 49228 & 52808 & 56446 & 60133 & 63853 & 67594 & 71342 & 75068 \\
\hline Agriculture & 5.95 & 133423 & 141369 & 149782 & 158692 & 168129 & 178127 & 188720 & 199946 & 211843 & 224453 & 237818 & 251986 \\
\hline Coal Industry & 6.75 & 29663 & 31681 & 33831 & 36121 & 38563 & 41167 & 43942 & 46901 & 50057 & 53422 & 57011 & 60839 \\
\hline Petroleum \& Gas & 7.23 & 73956 & 79401 & 85221 & 91445 & 98097 & 105206 & 112805 & 120927 & 129610 & 138891 & 148812 & 159417 \\
\hline Electricity & 6.64 & 85554 & 91236 & 97290 & 103741 & 110618 & 117951 & 125772 & 134114 & 143013 & 152509 & 162642 & 173455 \\
\hline Light Industries & 6.15 & 435402 & 462118 & 490468 & 520564 & 552514 & 586441 & 622474 & 660753 & 701422 & 744639 & 790571 & 839392 \\
\hline Chemicals & 6.37 & 207074 & 220337 & 234425 & 249397 & 265305 & 282209 & 300176 & 319275 & 339578 & 361165 & 384117 & 408522 \\
\hline Metals Industry & 6.84 & 223378 & 238783 & 255215 & 272748 & 291450 & 311400 & 332685 & 355394 & 379622 & 405473 & 433054 & 462481 \\
\hline Machinery \& & 6.73 & 113297 & 120954 & 129119 & 137829 & 147116 & 157021 & 167584 & 178851 & 190868 & 203686 & 217359 & 231943 \\
\hline Equipment & 6.58 & 107895 & 115002 & 122573 & 130640 & 139235 & 148394 & 158156 & 168562 & 1796 & 191486 & 204100 & 217553 \\
\hline Electrical \& Instrument & 6.36 & 93840 & 99780 & 106100 & 112828 & 119986 & 127605 & 135715 & 144350 & 153546 & 163342 & 173777 & 184896 \\
\hline Electronic \& Computer & 5.35 & 101760 & 107014 & 112578 & 118488 & 124744 & 131368 & 138392 & 1 & 153752 & 162152 & 171079 & 180566 \\
\hline Construction & 6.75 & 249078 & 265903 & 283861 & 303027 & 323488 & 345333 & 368655 & 393555 & 420138 & 448519 & 478820 & 511171 \\
\hline Transportation & 6.46 & 103405 & 110118 & 117255 & 124848 & 132924 & 141516 & 150657 & 160384 & 170737 & 181756 & 193486 & 205973 \\
\hline Telecom \& Software & 6.67 & 49797 & 53114 & 56651 & 60421 & 64443 & 68733 & 73310 & 78196 & 83410 & 88978 & 94923 & 101273 \\
\hline Business Services & 6.21 & 273149 & 290077 & 308050 & 327141 & 347422 & 368971 & 391875 & 416227 & 442122 & 469666 & 498971 & 530154 \\
\hline Finance \& Insurance & 6.98 & 115599 & 123594 & 132149 & 141309 & 151119 & 161629 & 172895 & 184975 & 197933 & 211837 & 226762 & 242788 \\
\hline Real Estate & 8.41 & 80086 & 86740 & 93961 & 101799 & 110312 & 119559 & 129610 & 140536 & 152417 & 165342 & 179406 & 194714 \\
\hline
\end{tabular}

\section{The Impacts of the Shrinkage in Goods Exports on the Chinese Economy}

\subsection{Simulation Scenarios}

Multi-national models study the impacts of the Sino-US trade war on the trade relation of China with the United States and other countries, while single-national models of China focus on the impacts of the Sino-US trade war on GDP growth, consumption, export, import, the balance of payment and the changes in the production of industries in China. This paper tries to analyze the below impacts of these shocks schemes may cause by the Sino-US trade war on the Chinese economy by simulation and the possible measures to hedge the impacts. In addition to the baseline scenario, 3 alternative simulations are attempted for comparison in order to see the impacts of the Sino-US trade war and 2 simulations of hedging the impacts. Contents of these 5 alternative scenarios (S1-S5) are explained briefly in Table 4.

Table 4. Simulation Scenarios

\begin{tabular}{cl}
\hline Scenario & \multicolumn{1}{c}{ Contents } \\
\hline S0 & The baseline scenario (the scale of Goods exports increase $5 \%$ every year) (See Table 3$)$ \\
S1 & All goods exports scale $0 \%$ increase (5 points decrease from the baseline by 2019) \\
S2 & $\begin{array}{l}\text { Selected three key industry's goods exports scale by }-5 \% \text { (10 points decrease from the baseline scenario by from } \\
\text { 2019) }\end{array}$ \\
S3 & All goods exports industries scale $-5 \%$ decrease (10 points decrease from the baseline scenario by from 2019) \\
S4 & S3+Yuan's value is depreciation of 20\% by 2019, hedge the goods exports fall \\
S5 & S3 + Real investment 1 points increase from the baseline scenario by 2019, hedge the goods exports fall \\
\hline
\end{tabular}

\subsection{Simulation Results}

Selected results of the simulation are shown from Table 5A, 5B to 7A, 7B and Table 8, 9 for key macroeconomic variables and gross outputs by industry. Table A shows the results of shock scenario compared with the baseline scenario, while Table B shows that the 1 percentage point of total exports reduction corresponds to the changes in other indicators.

Scenario S1 indicates the effects of the decline of all goods exports scale from $5 \%$ (the baseline level) to $0 \%$. We can obtain the following observation from Table 5A and 5B. In the macroeconomic level, if all goods export scale decrease 5\% (this means the goods exports of China will not increase again from 2019), that will cause a 
significant reduction in nominal GDP, and a slight reduction in real GDP because the exports scale decrease leads to a significant decline in GDP deflator. And real private consumption decreases, but real government consumption increases. And the total real imports decline more than the total real exports that mean the goods exports compare large scale imports. Trade surplus increases, this means the decline in total exports caused by the decrease in goods exports is less than the decline in total imports. In the industry level, real production declines especially in Electronic \& Computer, Electrical \& Instrument, and Light Industries. There is a positive impact on Petroleum \& Gas, Coal Industry, Metals Industry, and Transportation. Other industries suffer from positive or negative effects, but all are relatively small. Table 5B shows the change of other indicators by 1 percentage point decline in exports. The situation can be seen more clearly by Table 5B.

Scenario S2 indicates the effects of the selected three key industry's goods exports scale by $-5 \%$ (that means 10 percentage points decline from baseline scenario from 2019). The selected key industries are electronic \& computer, electrical \& instrument and light industries, accounted for $30.5 \%, 12.9 \%$ and $27.6 \%$ of the total goods exports of China, respectively in 2018 . The total share of three industries is more than $70 \%$. From the simulation results show in Table $6 \mathrm{~A}$ and $6 \mathrm{~B}$, we can obtain the following observation. In the macroeconomic level, if the three key industry's goods exports scale decrease $-5 \%$, that will cause a significant reduction in nominal GDP $(-4.47 \%$ in $2019,-23.65 \%$ in 2025 and $-31.5 \%$ in 2030$)$ and in GDP deflator $(-4.42 \%$ in $2019,-23.09 \%$ in 2025 and $-30.34 \%$ in 2030$)$, and a small reduction in real GDP (-0.05\% in $2019,-0.74$ in 2025 and $-1.65 \%$ in 2030$)$. And real private consumption decreases $(-0.57 \%$ in $2019,-3.23 \%$ in 2025 and $-4.53 \%$ in 2030$)$, but real government consumption has a slight increase. And the total real imports decline more than the total real exports. Trade surplus increases by 2024 and declines from 2025, becomes a negative value by 2030. In the industry level, real production declines especially in Electronic \& Computer, Electrical \& Instrument and Light Industries, and increases in Petroleum \& Gas, Coal Industry, Metals Industry, and Transportation. To other industries, positive or negative effects are relatively small. The situation can be seen more clearly by Table $6 \mathrm{~B}$.

Scenario S3 indicates the effects of all goods exports scale by $-5 \%$ (that means 10 percentage points decline from baseline scenario from 2019). As can be seen from Tables 7A, the situation of impact is similar to the scenario to S2, but the impact is greater. The situation can be seen more clearly by Table 7B.

Scenario S4 is attempted from the point of view of hedging negative impacts of goods exports decline caused by the Sino-US trade war (i.e., GDP reduction) with means of exchange rate devaluation. As can be seen from Tables $8 \mathrm{~A}$ and $8 \mathrm{~B}$, devaluation of Yuan by $20 \%$ significantly hedged the decrease in nominal GDP (from $-5.29 \%$ to $13.61 \%$ in $2019,-27.68 \%$ to $-12.62 \%$ in 2025 and $-35.64 \%$ to $-22.77 \%$ in 2030 ), but it has little impact on real GDP, because currency depreciation mainly changes the price (see Table 8).

Scenario S5 is attempted from the point of view of hedging negative impacts of goods exports decline caused by the Sino-US trade war (i.e., GDP reduction) with means of rising real investment. As can be seen from Tables 9A and $9 \mathrm{~B}$, an increase in real investment by $1 \%$ from 2019 has a relatively obvious hedging effect. In the macroeconomic level, it exacerbates the loss of nominal GDP by 2022, but then the hedging effect gradually appear, it has already hedged the four-fifths losses caused by the reduction of the goods exports by 2030 . To Real GDP losses, the hedging effect is gradually increasing, and, it is over $90 \%$ by 2030 . To real private consumption and real government consumption, the hedging effect is also gradually increasing, and, it is over $50 \%$ by 2030 . The increase in real investment has a complicated impact on total imports and total exports. It has intensified the decline in total exports but has significantly hedged the decline in total imports caused by the decline in goods exports. As a result, the trade deficit has risen sharply (see Table 9).

Table 5A. S1 Compare with Baseline Scenario S0 (\%)

\begin{tabular}{|c|c|c|c|c|c|c|c|c|c|c|c|c|}
\hline & 2019 & 2020 & 2021 & 2022 & 2023 & 2024 & 2025 & 2026 & 2027 & 2028 & 2029 & 2030 \\
\hline Nominal GDP & -2.65 & -5.14 & -7.51 & -9.68 & -11.7 & -13.5 & -15.3 & -16.9 & -18.3 & -19.6 & -20.8 & -21.8 \\
\hline Real GDP & -0.03 & -0.06 & -0.10 & -0.16 & -0.23 & -0.31 & -0.40 & -0.50 & -0.60 & -0.71 & -0.82 & -0.93 \\
\hline GDP Deflator & -2.63 & -5.08 & -7.41 & -9.54 & -11.5 & -13.3 & -14.9 & -16.4 & -17.8 & -19.0 & -20.1 & -21.1 \\
\hline Real Consumption & -0.33 & -0.65 & -0.95 & -1.23 & -1.51 & -1.76 & -2.01 & -2.23 & -2.44 & -2.64 & -2.81 & -2.97 \\
\hline Real Gov Consumption & 0.04 & 0.09 & 0.13 & 0.17 & 0.21 & 0.25 & 0.29 & 0.33 & 0.36 & 0.40 & 0.43 & 0.46 \\
\hline Real Exports & -0.61 & -1.23 & -1.83 & -2.45 & -3.07 & -3.70 & -4.34 & -4.99 & -5.65 & -6.32 & -7.01 & -7.71 \\
\hline Real Imports & -1.31 & -2.55 & -3.74 & -4.83 & -5.84 & -6.78 & -7.64 & -8.43 & -9.15 & -9.80 & -10.3 & -10.9 \\
\hline Trade Surplus & 2.25 & 3.94 & 5.35 & 6.15 & 6.60 & 6.74 & 6.60 & 6.20 & 5.57 & 4.69 & 3.58 & 2.23 \\
\hline Agriculture & -0.02 & -0.05 & -0.07 & -0.09 & -0.11 & -0.13 & -0.15 & -0.16 & -0.18 & -0.19 & -0.19 & -0.20 \\
\hline Coal Industry & 0.11 & 0.20 & 0.29 & 0.38 & 0.45 & 0.52 & 0.58 & 0.63 & 0.68 & 0.72 & 0.75 & 0.78 \\
\hline
\end{tabular}




\begin{tabular}{lllllllllllll}
\hline Petroleum \& Gas & 0.38 & 0.72 & 1.05 & 1.34 & 1.61 & 1.84 & 2.05 & 2.24 & 2.40 & 2.54 & 2.65 & 2.74 \\
Electricity & -0.01 & -0.03 & -0.05 & -0.07 & -0.08 & -0.10 & -0.12 & -0.14 & -0.16 & -0.18 & -0.20 & -0.22 \\
Light Industries & -0.13 & -0.26 & -0.38 & -0.49 & -0.59 & -0.69 & -0.78 & -0.86 & -0.94 & -1.01 & -1.06 & -1.11 \\
Chemicals & 0.00 & 0.01 & 0.01 & 0.02 & 0.02 & 0.02 & 0.03 & 0.03 & 0.04 & 0.04 & 0.05 & 0.05 \\
Metals Industry & 0.09 & 0.18 & 0.27 & 0.35 & 0.43 & 0.51 & 0.58 & 0.64 & 0.70 & 0.76 & 0.82 & 0.86 \\
Machinery \& Equipment & 0.02 & 0.05 & 0.08 & 0.11 & 0.13 & 0.16 & 0.19 & 0.22 & 0.25 & 0.28 & 0.31 & 0.34 \\
Transport Equipment & -0.03 & -0.05 & -0.08 & -0.11 & -0.14 & -0.18 & -0.21 & -0.24 & -0.28 & -0.31 & -0.34 & -0.38 \\
Electrical \& Instrument & -0.20 & -0.38 & -0.54 & -0.68 & -0.81 & -0.91 & -1.01 & -1.09 & -1.15 & -1.20 & -1.24 & -1.27 \\
Electronic \& Computer & -0.87 & -1.66 & -2.32 & -2.92 & -3.44 & -3.86 & -4.20 & -4.46 & -4.64 & -4.74 & -4.78 & -4.75 \\
Construction & 0.01 & 0.02 & 0.02 & 0.03 & 0.03 & 0.04 & 0.04 & 0.05 & 0.05 & 0.05 & 0.06 & 0.06 \\
Transportation & 0.20 & 0.38 & 0.55 & 0.69 & 0.83 & 0.95 & 1.05 & 1.14 & 1.22 & 1.28 & 1.33 & 1.37 \\
Telecom \& Software & 0.02 & 0.03 & 0.02 & 0.01 & -0.01 & -0.04 & -0.07 & -0.12 & -0.16 & -0.22 & -0.27 & -0.33 \\
Business Services & 0.09 & 0.17 & 0.24 & 0.30 & 0.35 & 0.39 & 0.42 & 0.44 & 0.45 & 0.45 & 0.45 & 0.43 \\
Finance \& Insurance & 0.02 & 0.03 & 0.04 & 0.05 & 0.06 & 0.06 & 0.06 & 0.05 & 0.04 & 0.03 & 0.02 & 0.00 \\
Real Estate & -0.01 & -0.02 & -0.03 & -0.04 & -0.06 & -0.08 & -0.10 & -0.12 & -0.14 & -0.17 & -0.19 & -0.22 \\
Public Services & 0.02 & 0.04 & 0.05 & 0.07 & 0.08 & 0.09 & 0.10 & 0.11 & 0.12 & 0.13 & 0.14 & 0.15 \\
\hline
\end{tabular}

Table 5B. S1 Compare with Real Export 1 point Decrease (\%)

\begin{tabular}{|c|c|c|c|c|c|c|c|c|c|c|c|c|}
\hline 1\% Exports Vs Others & 2019 & 2020 & 2021 & 2022 & 2023 & 2024 & 2025 & 2026 & 2027 & 2028 & 2029 & 2030 \\
\hline Nominal GDP & 4.32 & 4.18 & 4.11 & 3.96 & 3.81 & 3.67 & 3.52 & 3.38 & 3.25 & 3.11 & 2.97 & 2.84 \\
\hline Rea & 4 & 0.05 & 6 & 0.07 & 8 & 8 & 0 . & 0.10 & 0 . & 1 & 0.12 & 0.12 \\
\hline GDP Deflator & 4.28 & 4.13 & 4.05 & 3.90 & 3.74 & 3.59 & 3.44 & 3.30 & 3.16 & 3.02 & 2.88 & 2.74 \\
\hline Real Consumption & 0.54 & 0.53 & 0.52 & 0.50 & 0.49 & 0.48 & 0.46 & 0.45 & 0.43 & 0.42 & 0.40 & 0.39 \\
\hline Real Gov Consumption & -0.07 & -0.07 & -0.07 & -0.07 & -0.07 & -0.07 & -0.07 & -0.07 & -0.06 & -0.06 & -0.06 & -0.06 \\
\hline Real Exports & 1.00 & 1.00 & 1.00 & 1.00 & 1.00 & 1.00 & 1.00 & 1.00 & 1.00 & 1.00 & 1.00 & 1.00 \\
\hline Real Imports & 2.14 & 2.08 & 2.05 & 1.97 & 1.90 & 1.83 & 1.76 & 1.69 & 1.62 & 1.55 & 1.48 & 1.41 \\
\hline Trade Surplus & -3.67 & -3.20 & -2.93 & -2.51 & -2.15 & -1.82 & -1.52 & -1.24 & -0.98 & -0.74 & -0.51 & -0.29 \\
\hline Agriculture & 0.04 & 0.04 & 0.04 & 0.04 & 0.04 & 0.04 & 0.03 & 0.03 & 0.03 & 0.03 & 0.03 & 0.03 \\
\hline Coal Industry & -0.17 & -0.17 & -0.16 & -0.15 & -0.15 & -0.14 & -0.13 & -0.13 & -0.12 & -0.11 & -0.11 & -0.10 \\
\hline Petroleum \&Gas & -0.61 & -0.59 & -0.57 & -0.55 & -0.52 & -0.50 & -0.47 & -0.45 & -0.42 & -0.40 & -0.38 & -0.36 \\
\hline Electricity & 0.02 & 0.02 & 0.03 & 0.03 & 0.03 & 0.03 & 0.03 & 0.03 & 0.03 & 0.03 & 0.03 & 0.03 \\
\hline Light Industries & 0.22 & 0.21 & 0.21 & 0.20 & 0.19 & 0.19 & 0.18 & 0.17 & 0.17 & 0.16 & 0.15 & 0.14 \\
\hline Chemicals & -0.01 & -0.01 & -0.01 & -0.01 & -0.01 & -0.01 & -0.01 & -0.01 & -0.01 & -0.01 & -0.01 & -0.01 \\
\hline Metals Ind & -0.15 & -0.15 & -0.15 & -0.14 & -0.14 & -0.14 & -0.13 & -0.13 & -0.12 & -0.12 & -0.12 & -0.11 \\
\hline Machinery \& Eq & -0.04 & -0.04 & -0.04 & -0.04 & -0.04 & -0.04 & -0.04 & -0.04 & -0.04 & -0.04 & -0.04 & -0.04 \\
\hline Transport Equi & 0.04 & 0.04 & 0.04 & 0.05 & 0.05 & 0.05 & 0.05 & 0.05 & 0.05 & 0.05 & 0.05 & 0.05 \\
\hline Electrical \& Ins & 0.33 & 0.31 & 0.29 & 0.28 & 0.26 & 0.25 & 0.23 & 0.22 & 0.20 & 0.19 & 0.18 & 0.16 \\
\hline Electronic \&C & 1.42 & 1.35 & 1.27 & 1.19 & 1.12 & 1.04 & 0.97 & 0.89 & 0.82 & 0.75 & 0.68 & 0.62 \\
\hline Cons & -0.01 & -0.01 & -0.01 & -0.01 & -0.01 & -0.01 & -0.01 & -0.01 & -0.01 & -0.01 & -0.01 & -0.01 \\
\hline Transportation & -0.32 & -0.31 & -0.30 & -0.28 & -0.27 & -0.26 & -0.24 & -0.23 & -0.22 & -0.20 & -0.19 & -0.18 \\
\hline Telecom \& Softwa & -0.03 & -0.02 & -0.01 & -0.01 & 0.00 & 0.01 & 0.02 & 0.02 & 0.03 & 0.03 & 0.04 & 0.04 \\
\hline Business Services & -0.15 & -0.14 & -0.13 & -0.12 & -0.11 & -0.10 & -0.10 & -0.09 & -0.08 & -0.07 & -0.06 & -0.06 \\
\hline Finance \& Insurance & -0.03 & -0.03 & -0.02 & -0.02 & -0.02 & -0.02 & -0.01 & -0.01 & -0.01 & -0.01 & 0.00 & 0.00 \\
\hline Real Estate & 0.01 & 0.01 & 0.02 & 0.02 & 0.02 & 0.02 & 0.02 & 0.02 & 0.03 & 0.03 & 0.03 & 0.03 \\
\hline Public Services & -0.03 & -0.03 & -0.03 & -0.03 & -0.03 & -0.02 & -0.02 & -0.02 & -0.02 & -0.02 & -0.02 & -0.02 \\
\hline
\end{tabular}

Table 6A. S2 Compare with Baseline Scenario S0 (\%)

\begin{tabular}{lcccccccccccc}
\hline & 2019 & 2020 & 2021 & 2022 & 2023 & 2024 & 2025 & 2026 & 2027 & 2028 & 2029 & 2030 \\
\hline Nominal GDP & -4.47 & -8.59 & -12.2 & -15.5 & -18.5 & -21.2 & -23.6 & -25.7 & -27.5 & -29.0 & -30.4 & -31.4 \\
Real GDP & -0.05 & -0.11 & -0.21 & -0.33 & -0.47 & -0.60 & -0.74 & -0.91 & -1.09 & -1.27 & -1.46 & -1.65 \\
GDP Deflator & -4.42 & -8.49 & -12.0 & -15.2 & -18.1 & -20.7 & -23.0 & -25.0 & -26.7 & -28.1 & -29.3 & -30.3 \\
\hline
\end{tabular}




\begin{tabular}{|c|c|c|c|c|c|c|c|c|c|c|c|c|}
\hline Real Consumption & -0.57 & -1.09 & -1.58 & -2.05 & -2.48 & -2.87 & -3.23 & -3.55 & -3.85 & -4.11 & -4.34 & -4.53 \\
\hline Real Gov Consumption & 0.09 & 0.17 & 0.25 & 0.32 & 0.39 & 0.46 & 0.53 & 0.58 & 0.64 & 0.69 & 0.73 & 0.77 \\
\hline Real Exports & -1.12 & -2.18 & -3.25 & -4.31 & -5.37 & -6.37 & -7.38 & -8.42 & -9.48 & -10.5 & -11.6 & -12.7 \\
\hline Real Imports & -2.25 & -4.36 & -6.24 & -7.92 & -9.44 & -10.8 & -12.1 & -13.1 & -14.1 & -14.9 & -15.5 & -16.1 \\
\hline Trade Surplus & 3.53 & 6.34 & 7.96 & 8.72 & 8.89 & 8.92 & 8.36 & 7.08 & 5.38 & 3.26 & 0.77 & -2.11 \\
\hline Agriculture & -0.06 & -0.11 & -0.16 & -0.21 & -0.25 & -0.29 & -0.33 & -0.36 & -0.38 & -0.40 & -0.42 & -0.42 \\
\hline Coal Industry & 0.25 & 0.47 & 0.67 & 0.84 & 0.98 & 1.10 & 1.20 & 1.28 & 1.35 & 1.40 & 1.43 & 1.45 \\
\hline Petroleum \& Gas & 0.74 & 1.41 & 2.01 & 2.53 & 2.98 & 3.39 & 3.73 & 4.01 & 4.23 & 4.40 & 4.52 & 4.59 \\
\hline Electricity & 0.02 & 0.04 & 0.04 & 0.04 & 0.03 & 0.01 & -0.01 & -0.03 & -0.06 & -0.09 & -0.12 & -0.15 \\
\hline Light Industries & -0.30 & -0.57 & -0.82 & -1.04 & -1.24 & -1.42 & -1.57 & -1.70 & -1.82 & -1.91 & -1.98 & -2.03 \\
\hline Chemicals & 0.13 & 0.24 & 0.33 & 0.40 & 0.46 & 0.51 & 0.56 & 0.58 & 0.60 & 0.61 & 0.61 & 0.61 \\
\hline Metals Industry & 0.29 & 0.55 & 0.78 & 0.98 & 1.16 & 1.32 & 1.46 & 1.57 & 1.67 & 1.75 & 1.81 & 1.85 \\
\hline Machinery \& Equipment & 0.24 & 0.46 & 0.64 & 0.79 & 0.92 & 1.03 & 1.12 & 1.18 & 1.23 & 1.27 & 1.29 & 1.30 \\
\hline Transport Equipment & 0.14 & 0.25 & 0.32 & 0.37 & 0.39 & 0.40 & 0.39 & 0.36 & 0.31 & 0.26 & 0.20 & 0.14 \\
\hline Electrical \& Instrument & -0.48 & -0.89 & -1.25 & -1.56 & -1.82 & -2.01 & -2.16 & -2.29 & -2.37 & -2.43 & -2.45 & -2.45 \\
\hline Electronic \& Computer & -2.24 & -4.15 & -5.80 & -7.20 & -8.32 & -9.13 & -9.69 & -10.0 & -10.2 & -10.3 & -10.2 & -9.95 \\
\hline Construction & 0.02 & 0.03 & 0.04 & 0.06 & 0.07 & 0.07 & 0.07 & 0.08 & 0.08 & 0.09 & 0.09 & 0.09 \\
\hline Transportation & 0.36 & 0.68 & 0.97 & 1.22 & 1.43 & 1.63 & 1.79 & 1.92 & 2.03 & 2.11 & 2.16 & 2.19 \\
\hline Telecom \& Software & 0.02 & 0.02 & 0.00 & -0.04 & -0.09 & -0.15 & -0.22 & -0.30 & -0.38 & -0.47 & -0.56 & -0.65 \\
\hline Business Services & 0.15 & 0.29 & 0.41 & 0.51 & 0.58 & 0.65 & 0.70 & 0.72 & 0.74 & 0.73 & 0.72 & 0.69 \\
\hline Finance \& Insurance & 0.04 & 0.07 & 0.09 & 0.11 & 0.12 & 0.12 & 0.12 & 0.11 & 0.10 & 0.08 & 0.06 & 0.03 \\
\hline Real Estate & -0.01 & -0.03 & -0.05 & -0.07 & -0.10 & -0.13 & -0.16 & -0.19 & -0.23 & -0.26 & -0.30 & -0.34 \\
\hline Public Services & 0.05 & 0.09 & 0.12 & 0.15 & 0.18 & 0.20 & 0.21 & 0.23 & 0.24 & 0.25 & 0.26 & 0.27 \\
\hline
\end{tabular}

Table 6B. S2 Compare with Real Export 1 point Decrease (\%)

\begin{tabular}{|c|c|c|c|c|c|c|c|c|c|c|c|c|}
\hline 1\% Exports Vs Others & 2019 & 2020 & 2021 & 2022 & 2023 & 2024 & 2025 & 2026 & 2027 & 2028 & 2029 & 2030 \\
\hline Nominal GDP & 4.00 & 3.94 & 3.77 & 3.61 & 3.45 & 3.34 & 3.21 & 3.05 & 2.91 & 2.76 & 2.62 & 2.48 \\
\hline Real GDP & 0.05 & 0.05 & 0.06 & 0.08 & 0.09 & 0.09 & 0.10 & 0.11 & 0.11 & 0.12 & 0.13 & 0.13 \\
\hline GDP Deflator & 3.95 & 3.89 & 3.72 & 3.54 & 3.38 & 3.26 & 3.13 & 2.97 & 2.82 & 2.67 & 2.53 & 2.39 \\
\hline Real Consumption & 0.51 & 0.50 & 0.49 & 0.47 & 0.46 & 0.45 & 0.44 & 0.42 & 0.41 & 0.39 & 0.37 & 0.36 \\
\hline Real Gov Consumption & -0.08 & -0.08 & -0.08 & -0.08 & -0.07 & -0.07 & -0.07 & -0.07 & -0.07 & -0.07 & -0.06 & -0.06 \\
\hline Real Exports & 1.00 & 1.00 & 1.00 & 1.00 & 1.00 & 1.00 & 1.00 & 1.00 & 1.00 & 1.00 & 1.00 & 1.00 \\
\hline Real Imports & 2.01 & 2.00 & 1.92 & 1.84 & 1.76 & 1.71 & 1.64 & 1.57 & 1.49 & 1.41 & 1.34 & 1.27 \\
\hline Trade Surplus & -3.16 & -2.90 & -2.45 & -2.02 & -1.66 & -1.40 & -1.13 & -0.84 & -0.57 & -0.31 & -0.07 & 0.17 \\
\hline Agriculture & 0.05 & 0.05 & 0.05 & 0.05 & 0.05 & 0.05 & 0.04 & 0.04 & 0.04 & 0.04 & 0.04 & 0.03 \\
\hline Coal Industry & -0.22 & -0.22 & -0.20 & -0.19 & -0.18 & -0.17 & -0.16 & -0.15 & -0.14 & -0.13 & -0.12 & -0.11 \\
\hline Petroleum \&Gas & -0.66 & -0.65 & -0.62 & -0.59 & -0.56 & -0.53 & -0.51 & -0.48 & -0.45 & -0.42 & -0.39 & -0.36 \\
\hline Electricity & -0.02 & -0.02 & -0.01 & -0.01 & -0.01 & 0.00 & 0.00 & 0.00 & 0.01 & 0.01 & 0.01 & 0.01 \\
\hline Light Industries & 0.27 & 0.26 & 0.25 & 0.24 & 0.23 & 0.22 & 0.21 & 0.20 & 0.19 & 0.18 & 0.17 & 0.16 \\
\hline Chemicals & -0.11 & -0.11 & -0.10 & -0.09 & -0.09 & -0.08 & -0.08 & -0.07 & -0.06 & -0.06 & -0.05 & -0.05 \\
\hline Metals Industry & -0.26 & -0.25 & -0.24 & -0.23 & -0.22 & -0.21 & -0.20 & -0.19 & -0.18 & -0.17 & -0.16 & -0.15 \\
\hline Machinery \& Equipment & -0.22 & -0.21 & -0.20 & -0.18 & -0.17 & -0.16 & -0.15 & -0.14 & -0.13 & -0.12 & -0.11 & -0.10 \\
\hline Transport Equipment & -0.12 & -0.11 & -0.10 & -0.09 & -0.07 & -0.06 & -0.05 & -0.04 & -0.03 & -0.02 & -0.02 & -0.01 \\
\hline Electrical \& Instrument & 0.43 & 0.41 & 0.38 & 0.36 & 0.34 & 0.32 & 0.29 & 0.27 & 0.25 & 0.23 & 0.21 & 0.19 \\
\hline Electronic \&Computer & 2.01 & 1.90 & 1.79 & 1.67 & 1.55 & 1.43 & 1.31 & 1.20 & 1.09 & 0.98 & 0.88 & 0.78 \\
\hline Construction & -0.02 & -0.01 & -0.01 & -0.01 & -0.01 & -0.01 & -0.01 & -0.01 & -0.01 & -0.01 & -0.01 & -0.01 \\
\hline Transportation & -0.32 & -0.31 & -0.30 & -0.28 & -0.27 & -0.26 & -0.24 & -0.23 & -0.21 & -0.20 & -0.19 & -0.17 \\
\hline Telecom \& Software & -0.02 & -0.01 & 0.00 & 0.01 & 0.02 & 0.02 & 0.03 & 0.04 & 0.04 & 0.04 & 0.05 & 0.05 \\
\hline Business Services & -0.14 & -0.13 & -0.13 & -0.12 & -0.11 & -0.10 & -0.09 & -0.09 & -0.08 & -0.07 & -0.06 & -0.05 \\
\hline Finance \& Insurance & -0.03 & -0.03 & -0.03 & -0.03 & -0.02 & -0.02 & -0.02 & -0.01 & -0.01 & -0.01 & 0.00 & 0.00 \\
\hline Real Estate & 0.01 & 0.01 & 0.01 & 0.02 & 0.02 & 0.02 & 0.02 & 0.02 & 0.02 & 0.03 & 0.03 & 0.03 \\
\hline Public Services & -0.04 & -0.04 & -0.04 & -0.04 & -0.03 & -0.03 & -0.03 & -0.03 & -0.03 & -0.02 & -0.02 & -0.02 \\
\hline
\end{tabular}


Table 7A. S3 Compare with Baseline Scenario S0 (\%)

\begin{tabular}{|c|c|c|c|c|c|c|c|c|c|c|c|c|}
\hline & 2019 & 2020 & 2021 & 2022 & 2023 & 2024 & 2025 & 2026 & 2027 & 2028 & 2029 & 2030 \\
\hline Nominal GDP & -5.29 & -10.1 & -14.3 & -18.1 & -21.5 & -24.5 & -27.1 & -29.5 & -31.5 & -33.1 & -34.5 & -35.6 \\
\hline Real GDP & -0.07 & -0.15 & -0.27 & -0.42 & -0.60 & -0.79 & -0.98 & -1.17 & -1.40 & -1.63 & -1.88 & -2.12 \\
\hline GDP Deflator & -5.23 & -9.96 & -14.1 & -17.8 & -21.0 & -23.9 & -26.4 & -28.7 & -30.5 & -32.0 & -33.2 & -34.2 \\
\hline Real Consumption & -0.68 & -1.30 & -1.89 & -2.43 & -2.94 & -3.40 & -3.81 & -4.18 & -4.51 & -4.80 & -5.05 & -5.26 \\
\hline Real Gov Consumption & 0.09 & 0.17 & 0.26 & 0.33 & 0.41 & 0.48 & 0.56 & 0.63 & 0.69 & 0.75 & 0.81 & 0.86 \\
\hline Real Exports & -1.28 & -2.52 & -3.79 & -5.07 & -6.35 & -7.64 & -8.92 & -10.1 & -11.5 & -12.8 & -14.2 & -15.6 \\
\hline Real Imports & -2.63 & -5.06 & -7.25 & -9.20 & -10.9 & -12.5 & -13.9 & -15.2 & -16.2 & -17.1 & -17.8 & -18.4 \\
\hline Trade Surplus & 4.26 & 7.40 & 9.17 & 9.86 & 9.76 & 8.96 & 7.79 & 6.21 & 3.67 & 0.62 & -2.93 & -6.95 \\
\hline Agriculture & -0.05 & -0.10 & -0.16 & -0.21 & -0.25 & -0.30 & -0.34 & -0.37 & -0.40 & -0.43 & -0.44 & -0.45 \\
\hline Coal Industry & 0.22 & 0.41 & 0.58 & 0.73 & 0.86 & 0.97 & 1.06 & 1.14 & 1.20 & 1.25 & 1.29 & 1.31 \\
\hline Petroleum \& Gas & 0.76 & 1.45 & 2.07 & 2.62 & 3.10 & 3.52 & 3.88 & 4.19 & 4.43 & 4.61 & 4.74 & 4.82 \\
\hline Electricity & -0.03 & -0.06 & -0.10 & -0.14 & -0.18 & -0.22 & -0.26 & -0.30 & -0.34 & -0.37 & -0.41 & -0.44 \\
\hline Light Industries & -0.27 & -0.53 & -0.77 & -0.99 & -1.19 & -1.37 & -1.54 & -1.68 & -1.80 & -1.90 & -1.99 & -2.05 \\
\hline Chemicals & 0.00 & 0.01 & 0.01 & 0.00 & 0.00 & -0.01 & -0.01 & 0.00 & 0.00 & 0.01 & 0.01 & 0.02 \\
\hline Metals Industry & 0.18 & 0.36 & 0.52 & 0.66 & 0.80 & 0.93 & 1.04 & 1.16 & 1.25 & 1.34 & 1.41 & 1.48 \\
\hline Machinery \& Equipment & 0.04 & 0.09 & 0.14 & 0.18 & 0.23 & 0.28 & 0.33 & 0.38 & 0.43 & 0.47 & 0.52 & 0.55 \\
\hline Transport Equipment & -0.06 & -0.11 & -0.17 & -0.24 & -0.30 & -0.37 & -0.43 & -0.49 & -0.55 & -0.61 & -0.66 & -0.71 \\
\hline Electrical \& Instrument & -0.41 & -0.77 & -1.08 & -1.36 & -1.59 & -1.78 & -1.93 & -2.03 & -2.12 & -2.18 & -2.21 & -2.21 \\
\hline Electronic \& Computer & -1.80 & -3.33 & -4.67 & -5.79 & -6.70 & -7.38 & -7.84 & -8.05 & -8.18 & -8.17 & -8.02 & -7.77 \\
\hline Construction & 0.02 & 0.04 & 0.05 & 0.07 & 0.08 & 0.09 & 0.09 & 0.09 & 0.10 & 0.10 & 0.10 & 0.11 \\
\hline Transportation & 0.40 & 0.76 & 1.08 & 1.37 & 1.62 & 1.83 & 2.01 & 2.17 & 2.28 & 2.37 & 2.43 & 2.46 \\
\hline Telecom \& Software & 0.04 & 0.05 & 0.04 & 0.02 & -0.03 & -0.09 & -0.17 & -0.25 & -0.34 & -0.44 & -0.54 & -0.65 \\
\hline Business Services & 0.19 & 0.35 & 0.50 & 0.62 & 0.71 & 0.79 & 0.85 & 0.89 & 0.90 & 0.90 & 0.88 & 0.85 \\
\hline Finance \& Insurance & 0.04 & 0.07 & 0.09 & 0.10 & 0.11 & 0.11 & 0.11 & 0.10 & 0.08 & 0.06 & 0.03 & 0.00 \\
\hline Real Estate & -0.01 & -0.03 & -0.06 & -0.09 & -0.12 & -0.15 & -0.19 & -0.23 & -0.27 & -0.31 & -0.35 & -0.39 \\
\hline Public Services & 0.04 & 0.07 & 0.10 & 0.13 & 0.15 & 0.17 & 0.19 & 0.21 & 0.22 & 0.23 & 0.25 & 0.26 \\
\hline
\end{tabular}

Table 7B. S3 Compare with Real Export 1 point Decrease (\%)

\begin{tabular}{lllllllllllll}
\hline 1\% Exports Vs Others & 2019 & 2020 & 2021 & 2022 & 2023 & 2024 & 2025 & 2026 & 2027 & 2028 & 2029 & 2030 \\
\hline Nominal GDP & 4.15 & 4.00 & 3.79 & 3.58 & 3.39 & 3.21 & 3.05 & 2.90 & 2.73 & 2.58 & 2.42 & 2.28 \\
Real GDP & 0.05 & 0.06 & 0.07 & 0.08 & 0.09 & 0.10 & 0.11 & 0.11 & 0.12 & 0.13 & 0.13 & 0.14 \\
GDP Deflator & 4.10 & 3.95 & 3.73 & 3.51 & 3.32 & 3.13 & 2.97 & 2.82 & 2.65 & 2.49 & 2.33 & 2.19 \\
Real Consumption & 0.53 & 0.52 & 0.50 & 0.48 & 0.46 & 0.44 & 0.43 & 0.41 & 0.39 & 0.37 & 0.35 & 0.34 \\
Real Gov Consumption & -0.07 & -0.07 & -0.07 & -0.07 & -0.06 & -0.06 & -0.06 & -0.06 & -0.06 & -0.06 & -0.06 & -0.05 \\
Real Exports & 1.00 & 1.00 & 1.00 & 1.00 & 1.00 & 1.00 & 1.00 & 1.00 & 1.00 & 1.00 & 1.00 & 1.00 \\
Real Imports & 2.06 & 2.01 & 1.91 & 1.81 & 1.73 & 1.64 & 1.56 & 1.49 & 1.41 & 1.33 & 1.25 & 1.18 \\
Trade Surplus & -3.34 & -2.93 & -2.42 & -1.94 & -1.54 & -1.17 & -0.87 & -0.61 & -0.32 & -0.05 & 0.21 & 0.44 \\
Agriculture & 0.04 & 0.04 & 0.04 & 0.04 & 0.04 & 0.04 & 0.04 & 0.04 & 0.04 & 0.03 & 0.03 & 0.03 \\
Coal Industry & -0.17 & -0.16 & -0.15 & -0.14 & -0.13 & -0.13 & -0.12 & -0.11 & -0.10 & -0.10 & -0.09 & -0.08 \\
Petroleum \& Gas & -0.59 & -0.58 & -0.55 & -0.52 & -0.49 & -0.46 & -0.44 & -0.41 & -0.38 & -0.36 & -0.33 & -0.31 \\
Electricity & 0.02 & 0.03 & 0.03 & 0.03 & 0.03 & 0.03 & 0.03 & 0.03 & 0.03 & 0.03 & 0.03 & 0.03 \\
Light Industries & 0.22 & 0.21 & 0.20 & 0.20 & 0.19 & 0.18 & 0.17 & 0.16 & 0.16 & 0.15 & 0.14 & 0.13 \\
Chemicals & 0.00 & 0.00 & 0.00 & 0.00 & 0.00 & 0.00 & 0.00 & 0.00 & 0.00 & 0.00 & 0.00 & 0.00 \\
Metals Industry & -0.14 & -0.14 & -0.14 & -0.13 & -0.13 & -0.12 & -0.12 & -0.11 & -0.11 & -0.10 & -0.10 & -0.09 \\
Machinery \& Equipment & -0.03 & -0.04 & -0.04 & -0.04 & -0.04 & -0.04 & -0.04 & -0.04 & -0.04 & -0.04 & -0.04 & -0.04 \\
Transport Equipment & 0.04 & 0.04 & 0.05 & 0.05 & 0.05 & 0.05 & 0.05 & 0.05 & 0.05 & 0.05 & 0.05 & 0.05 \\
Electrical \& Instrument & 0.32 & 0.30 & 0.29 & 0.27 & 0.25 & 0.23 & 0.22 & 0.20 & 0.18 & 0.17 & 0.15 & 0.14 \\
\hline
\end{tabular}




\begin{tabular}{lllllllllllll}
\hline Electronic \& Computer & 1.41 & 1.32 & 1.23 & 1.14 & 1.05 & 0.97 & 0.88 & 0.79 & 0.71 & 0.63 & 0.56 & 0.50 \\
Construction & -0.02 & -0.01 & -0.01 & -0.01 & -0.01 & -0.01 & -0.01 & -0.01 & -0.01 & -0.01 & -0.01 & -0.01 \\
Transportation & -0.31 & -0.30 & -0.29 & -0.27 & -0.25 & -0.24 & -0.23 & -0.21 & -0.20 & -0.18 & -0.17 & -0.16 \\
Telecom \& Software & -0.03 & -0.02 & -0.01 & 0.00 & 0.00 & 0.01 & 0.02 & 0.02 & 0.03 & 0.03 & 0.04 & 0.04 \\
Business Services & -0.15 & -0.14 & -0.13 & -0.12 & -0.11 & -0.10 & -0.10 & -0.09 & -0.08 & -0.07 & -0.06 & -0.05 \\
Finance \& Insurance & -0.03 & -0.03 & -0.02 & -0.02 & -0.02 & -0.01 & -0.01 & -0.01 & -0.01 & 0.00 & 0.00 & 0.00 \\
Real Estate & 0.01 & 0.01 & 0.02 & 0.02 & 0.02 & 0.02 & 0.02 & 0.02 & 0.02 & 0.02 & 0.02 & 0.03 \\
Public Services & -0.03 & -0.03 & -0.03 & -0.02 & -0.02 & -0.02 & -0.02 & -0.02 & -0.02 & -0.02 & -0.02 & -0.02 \\
\hline
\end{tabular}

Table 8. S4 Compare with Baseline Scenario S0 (\%)

\begin{tabular}{|c|c|c|c|c|c|c|c|c|c|c|c|c|}
\hline & 2019 & 2020 & 2021 & 2022 & 2023 & 2024 & 2025 & 2026 & 2027 & 2028 & 2029 & 2030 \\
\hline Nominal GDP & 13.6 & 7.88 & 2.76 & -1.79 & -5.84 & -9.42 & -12.6 & -15.4 & -17.8 & -19.7 & -21.4 & -22.7 \\
\hline Real GDP & -0.06 & -0.15 & -0.27 & -0.42 & -0.60 & -0.79 & -0.98 & -1.17 & -1.40 & -1.63 & -1.88 & -2.12 \\
\hline GDP Deflator & 13.6 & 8.04 & 3.04 & -1.37 & -5.28 & -8.70 & -11.7 & -14.4 & -16.6 & -18.4 & -19.9 & -21.1 \\
\hline Real Consumption & -0.67 & -1.30 & -1.89 & -2.43 & -2.94 & -3.40 & -3.81 & -4.18 & -4.51 & -4.80 & -5.05 & -5.26 \\
\hline Real Gov Consumption & 0.09 & 0.17 & 0.25 & 0.33 & 0.41 & 0.48 & 0.56 & 0.63 & 0.69 & 0.75 & 0.81 & 0.86 \\
\hline Real Exports & -1.26 & -2.52 & -3.79 & -5.07 & -6.35 & -7.64 & -8.92 & -10.1 & -11.5 & -12.8 & -14.2 & -15.6 \\
\hline Real Imports & -2.65 & -5.06 & -7.24 & -9.20 & -10.9 & -12.5 & -13.9 & -15.2 & -16.2 & -17.1 & -17.8 & -18.4 \\
\hline Trade Surplus & 4.44 & 7.40 & 9.17 & 9.86 & 9.76 & 8.96 & 7.79 & 6.21 & 3.67 & 0.61 & -2.93 & -6.95 \\
\hline Agriculture & -0.05 & -0.10 & -0.16 & -0.21 & -0.25 & -0.30 & -0.34 & -0.37 & -0.40 & -0.43 & -0.44 & -0.45 \\
\hline Coal Industry & 0.21 & 0.41 & 0.58 & 0.73 & 0.86 & 0.97 & 1.06 & 1.14 & 1.20 & 1.25 & 1.29 & 1.31 \\
\hline Petroleum \& Gas & 0.76 & 1.45 & 2.07 & 2.62 & 3.10 & 3.52 & 3.88 & 4.19 & 4.43 & 4.61 & 4.74 & 4.82 \\
\hline Electricity & -0.03 & -0.06 & -0.10 & -0.14 & -0.18 & -0.22 & -0.26 & -0.30 & -0.34 & -0.37 & -0.41 & -0.44 \\
\hline Light Industries & -0.27 & -0.53 & -0.77 & -0.99 & -1.19 & -1.37 & -1.54 & -1.68 & -1.80 & -1.90 & -1.99 & -2.05 \\
\hline Chemicals & 0.01 & 0.01 & 0.01 & 0.00 & 0.00 & -0.01 & -0.01 & 0.00 & 0.00 & 0.01 & 0.01 & 0.02 \\
\hline Metals Industry & 0.19 & 0.36 & 0.52 & 0.66 & 0.80 & 0.93 & 1.04 & 1.16 & 1.25 & 1.34 & 1.41 & 1.48 \\
\hline Machinery \& Equipment & 0.05 & 0.09 & 0.14 & 0.18 & 0.23 & 0.28 & 0.33 & 0.38 & 0.43 & 0.47 & 0.52 & 0.55 \\
\hline Transport Equipment & -0.05 & -0.11 & -0.17 & -0.24 & -0.30 & -0.37 & -0.43 & -0.49 & -0.55 & -0.61 & -0.66 & -0.71 \\
\hline Electrical \& Instrument & -0.41 & -0.77 & -1.09 & -1.36 & -1.59 & -1.78 & -1.93 & -2.03 & -2.12 & -2.18 & -2.21 & -2.21 \\
\hline Electronic \& Computer & -1.77 & -3.33 & -4.67 & -5.79 & -6.70 & -7.38 & -7.84 & -8.05 & -8.18 & -8.17 & -8.02 & -7.77 \\
\hline Construction & 0.02 & 0.04 & 0.05 & 0.07 & 0.08 & 0.09 & 0.09 & 0.09 & 0.10 & 0.10 & 0.10 & 0.11 \\
\hline Transportation & 0.40 & 0.76 & 1.08 & 1.37 & 1.62 & 1.83 & 2.01 & 2.17 & 2.28 & 2.37 & 2.43 & 2.46 \\
\hline Telecom \& Software & 0.04 & 0.05 & 0.04 & 0.02 & -0.03 & -0.09 & -0.17 & -0.25 & -0.34 & -0.44 & -0.54 & -0.65 \\
\hline Business Services & 0.19 & 0.35 & 0.50 & 0.62 & 0.71 & 0.79 & 0.85 & 0.89 & 0.90 & 0.90 & 0.88 & 0.85 \\
\hline Finance \& Insurance & 0.04 & 0.07 & 0.09 & 0.10 & 0.11 & 0.11 & 0.11 & 0.10 & 0.08 & 0.06 & 0.03 & 0.00 \\
\hline Real Estate & -0.01 & -0.03 & -0.06 & -0.09 & -0.12 & -0.15 & -0.19 & -0.23 & -0.27 & -0.31 & -0.35 & -0.39 \\
\hline Public Services & 0.04 & 0.07 & 0.10 & 0.13 & 0.15 & 0.17 & 0.19 & 0.21 & 0.22 & 0.23 & 0.25 & 0.26 \\
\hline
\end{tabular}

Table 9. S5 Compare with Baseline Scenario S0 (\%)

\begin{tabular}{|c|c|c|c|c|c|c|c|c|c|c|c|c|}
\hline & 2019 & 2020 & 2021 & 2022 & 2023 & 2024 & 2025 & 2026 & 2027 & 2028 & 2029 & 2030 \\
\hline Nominal GDP & -12.1 & -14.6 & -16.6 & -18.0 & -18.8 & -19.1 & -18.8 & -18.0 & -16.5 & -14.3 & -11.5 & -7.89 \\
\hline Real GDP & -0.06 & -0.09 & -0.13 & -0.17 & -0.20 & -0.23 & -0.24 & -0.26 & -0.26 & -0.25 & -0.23 & -0.20 \\
\hline GDP Deflator & -12.0 & -14.5 & -16.5 & -17.8 & -18.7 & -18.9 & -18.6 & -17.8 & -16.3 & -14.1 & -11.3 & -7.70 \\
\hline Real Consumption & -0.78 & -1.44 & -1.99 & -2.44 & -2.78 & -3.01 & -3.12 & -3.12 & -2.99 & -2.75 & -2.39 & -1.90 \\
\hline Real Gov Consumption & 0.08 & 0.19 & 0.31 & 0.44 & 0.58 & 0.73 & 0.88 & 1.03 & 1.18 & 1.32 & 1.45 & 1.57 \\
\hline Real Exports & -2.04 & -4.02 & -6.01 & -8.03 & -10.0 & -12.1 & -14.1 & -16.2 & -18.4 & -20.6 & -22.8 & -25.0 \\
\hline Real Imports & -1.29 & -2.35 & -3.08 & -3.46 & -3.52 & -3.26 & -2.67 & -1.73 & -0.44 & 1.21 & 3.25 & 5.66 \\
\hline Trade Surplus & -5.11 & -10.5 & -17.0 & -24.5 & -32.9 & -42.1 & -52.4 & -63.6 & -76.1 & -89.8 & -104 & -121 \\
\hline Agriculture & -0.13 & -0.21 & -0.25 & -0.26 & -0.23 & -0.16 & -0.07 & 0.05 & 0.19 & 0.36 & 0.54 & 0.74 \\
\hline Coal Industry & 0.08 & 0.19 & 0.32 & 0.46 & 0.61 & 0.77 & 0.93 & 1.09 & 1.24 & 1.39 & 1.52 & 1.65 \\
\hline Petroleum \& Gas & 0.35 & 0.69 & 0.98 & 1.22 & 1.41 & 1.55 & 1.64 & 1.66 & 1.62 & 1.53 & 1.38 & 1.17 \\
\hline
\end{tabular}




\begin{tabular}{lllllllllllll}
\hline Electricity & -0.06 & -0.08 & -0.06 & 0.01 & 0.11 & 0.24 & 0.40 & 0.60 & 0.81 & 1.05 & 1.31 & 1.59 \\
Light Industries & -0.31 & -0.54 & -0.71 & -0.81 & -0.86 & -0.84 & -0.76 & -0.63 & -0.44 & -0.20 & 0.08 & 0.41 \\
Chemicals & -0.23 & -0.40 & -0.54 & -0.64 & -0.70 & -0.74 & -0.75 & -0.74 & -0.72 & -0.68 & -0.63 & -0.58 \\
Metals Industry & 0.18 & 0.40 & 0.65 & 0.91 & 1.19 & 1.48 & 1.77 & 2.06 & 2.34 & 2.60 & 2.85 & 3.07 \\
Machinery \& Equipment & 0.26 & 0.58 & 0.93 & 1.31 & 1.72 & 2.15 & 2.60 & 3.05 & 3.51 & 3.97 & 4.42 & 4.87 \\
Transport Equipment & 0.14 & 0.34 & 0.57 & 0.84 & 1.14 & 1.47 & 1.83 & 2.22 & 2.64 & 3.09 & 3.55 & 4.04 \\
Electrical \& Instrument & -0.52 & -0.91 & -1.20 & -1.40 & -1.51 & -1.54 & -1.50 & -1.39 & -1.23 & -1.01 & -0.76 & -0.48 \\
Electronic \& Computer & -3.04 & -5.71 & -8.13 & -10.3 & -12.2 & -13.8 & -15.3 & -16.5 & -17.6 & -18.6 & -19.5 & -20.3 \\
Construction & 0.92 & 1.83 & 2.76 & 3.70 & 4.65 & 5.61 & 6.57 & 7.54 & 8.52 & 9.51 & 10.5 & 11.5 \\
Transportation & 0.27 & 0.55 & 0.82 & 1.07 & 1.30 & 1.52 & 1.72 & 1.90 & 2.06 & 2.20 & 2.32 & 2.42 \\
Telecom \& Software & 0.35 & 0.72 & 1.09 & 1.48 & 1.88 & 2.30 & 2.74 & 3.20 & 3.68 & 4.19 & 4.73 & 5.30 \\
Business Services & 0.07 & 0.17 & 0.27 & 0.38 & 0.49 & 0.61 & 0.74 & 0.88 & 1.02 & 1.18 & 1.35 & 1.54 \\
Finance \& Insurance & 0.02 & 0.09 & 0.19 & 0.33 & 0.50 & 0.70 & 0.93 & 1.19 & 1.47 & 1.78 & 2.11 & 2.47 \\
Real Estate & 0.04 & 0.14 & 0.29 & 0.51 & 0.77 & 1.09 & 1.45 & 1.85 & 2.31 & 2.80 & 3.34 & 3.92 \\
Public Services & 0.05 & 0.11 & 0.21 & 0.32 & 0.44 & 0.59 & 0.74 & 0.91 & 1.09 & 1.27 & 1.46 & 1.66 \\
\hline
\end{tabular}

\section{Summary and Conclusion}

In this paper, focusing on the goods exports scale decline caused by Sino-US trade war, we have investigated quantitatively its impacts on the macroeconomic level and industries in China from the point of view of growth, industrial structure and trade. We have adopted a methodology of the dynamic simulation for 2019-2030 by means of the CGE model. We have constructed a CGE model of China on the basis of the 2015 input-output table. We have obtained the results of dynamic simulation, which are summarized below.

According to the analysis in the previous section, we can summarize the impacts of the goods export reduction on the macroeconomic level and industries in China as follows. The goods exports reduction contributes to the decline of prices in the Chinese economy because the decline of goods exports compares a large scale import decline, and the nominal GDP decline is obviously but the impact on real GDP is not significant. This phenomenon indicates that a large part of China's goods exports are the final product exports, and the production of the final products require a large number of intermediate products imports such as core components, raw materials, and energy. This is one special aspect of the rapid growth of China's exports that has driven the growth of other relevant economies in the world over the years. Therefore, precisely because of the role of such model, the sharp shrinkage of China's goods exports will lead to a contraction in the goods imports, and will also have a negative impact on the economies which exports these core components, raw materials, and energy to China.

As can be seen from the summary above, the goods export scale decline caused by Sino-US trade war will bring negative influences to the macro economy and industries in China. In order to hedge the impact of the decline of goods exports scale, currency depreciation as a double-edged sword affecting import and export, ultimately only affects the price, and the effect on the real GDP is very limited. To increase the domestic real investment will result in a significant increase in imports and hedge the loss of nominal GDP and real GDP caused by the contraction in the goods exports, but cause a larger scale of trade deficit and therefore need to be used with caution. It should be noted that if the Sino-US trade war becomes long-term, it may lead to the withdrawal of foreign capital from China, and the impact of which may be more profound, but the analysis is not involved in this paper.

\section{References}

Dervis, K., de Melo, J., \& Robinson, S. (1982). General Equilibrium Models for Development Policy. Cambridge: Cambridge University Press.

Ezaki, M., \& Sun, L. (2000). Trade Liberalization and the Economy of China, A Dynamic CGE Analysis (1997-2010). Journal of Applied Input-Output Analysis, 6. Pan Pacific Association of Input-Output Studies, December, 37-78. https://doi.org/10.11107/papaios.9.3_4.

Li, C. D., He, C. T., \& Lin, C. W. (2018). Economic Impacts of the Possible China-US Trade War. Emerging Markets Finance and Trade, 54, 1557-1577. https://doi.org/10.1080/1540496X.2018.1446131

Shagdar, E., \& Nakajima, T. (2018). Economic Effects of the USA-China Trade War: CGE Analysis with the GTAP 9.0a Data Base. Discussion papers 1806, ERINA-Economic Research Institute for Northeast Asia. Retrieved from https://www.erina.or.jp/wp-content/uploads/2018/12/DP1806e.pdf 
Sun, L. (2012). Energy-saving and Emission-reducing Related Policies on Passenger Cars: A Simulation Analysis within a Hybrid CGE Model. China Population Resources and Environment, 22(7), 253-261 (in Chinese). http://dx.chinadoi.cn/10.3969/j.issn.1002-2104.2012.07.007

Tsutsumi, M. (2018). The Economic Consequences of the 2018 US-China Trade Conflict: A CGE Simulation. Analysis, Hitotsubashi University. $\quad$ Retrieved from http:/hermes-ir.lib.hit-u.ac.jp/rs/bitstream/10086/29763/1/DP67 6.pdf

\section{Copyrights}

Copyright for this article is retained by the author(s), with first publication rights granted to the journal.

This is an open-access article distributed under the terms and conditions of the Creative Commons Attribution license (http://creativecommons.org/licenses/by/4.0/). 